\title{
Public health and medicolegal implications of sleep apnoea
}

\author{
W.T. McNicholas and J. Krieger on behalf of the Task Force members. \\ Members of the Task Force: W.T. McNicholas (Chairman), P. Levy (Co-Chairman), \\ W. De Backer, N. Douglas, J. Krieger, O. Marrone, J. Montserrat, J.H. Peter, D. Rodenstein
}

\section{CONTENTS}

Definition of sleep apnoea syndrome . . . . . . . 1594

Epidemiology and clinical aspects . . . . . . . . . 1595

Sleep apnoea in the young and elderly . . . . 1596

Morbidity and mortality related to sleep apnoea

syndrome . . . . . . . . . . . . . . . . . . . . 1597

Impact of treatment of obstructive sleep apnoea/

hypopnoea on associated cardiovascular

morbidity . . . . . . . . . . . . . . . . . 1597

Association of sleep apnoea with road traffic

accidents . . . . . . . . . . . . . . . . . . . . . . 1597

Impact of treatment of obstructive sleep apnoea/

hypopnoea syndrome on accident risk . . . . 1598

Driving regulations concerning sleep apnoea and/or

The sleep apnoea syndrome represents something of a paradox in clinical medicine. On the one hand, this disorder has been recognised only in recent decades, and is still regarded as a niche interest by many clinicians, particularly those from clinical disciplines other than respiratory medicine, neurology and otolaryngology. On the other hand, the syndrome is now recognised as being very common and current epidemiological data indicate that sleep apnoea syndrome is second only to asthma in the prevalence league table of chronic respiratory disorders [1]. Furthermore, there is increasing evidence that sleep apnoea syndrome is associated with a considerable number of adverse sequelae, both behavioural and physical. Behavioural consequences include daytime sleepiness, impaired concentration and neuropsychological dysfunction, whereas physical consequences include cardiovascular disorders, particularly hypertension.

In 1997, the European Respiratory Society (ERS) established a Task Force to examine the Public Health and Medicolegal Implications of the Sleep Apnoea Syndrome with particular reference to the impact of sleepiness on patient and public safety. The following report represents the outcome of several meetings and discussions of the Task Force membership and also includes a review of current European Regulations excessive daytime sleepiness in different European

countries . . . . . . . . . . . . . . . . . . 1598

Methods . . . . . . . . . . . . . . . . . . . 1598

Results . . . . . . . . . . . . . . . . . . . . . . . 1599

Recommendations concerning driver licensing. . . . 1602 Association of sleep apnoea with other forms of accidents . . . . . . . . . . . . . . . . . . . . . . . 1604 Resource implications for the investigation and management of sleep apnoea syndrome . . . . . . . . . 1605 Appendix 1: Questionnaire sent to National Licensing

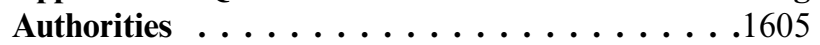
Appendix 2: Initial set of addresses of National Licensing Authorities. . . . . . . . . . . . . 1606

concerning driver licensing prepared by one of the members (J. Krieger).

\section{Definition of sleep apnoea syndrome}

Obstructive sleep apnoea syndrome (OSAS) is a condition characterised by repetitive obstruction of the upper airway, often resulting in oxygen desaturation and arousals from sleep. The principal daytime manifestation is excessive sleepiness but other symptoms such as unrefreshing sleep, poor concentration and fatigue are commonly reported. Early definitions of the syndrome were based on an apnoea frequency without reference to symptoms [2]. However, as epidemiological data from many studies made it clear that apnoeas during sleep are very common in the general population, the definition of a clinical syndrome was revised to include certain symptoms, particularly daytime sleepiness. Hypopnoeas were described as events of shallow breathing causing oxygen desaturation, which have similar clinical significance as apnoeas [3, 4]. In 1988, cases with hypopnoeas and no or few apnoeas were described, with clinical symptoms similar to OSAS [5]. Subsequently, the disorder began to be referred to as

Correspondence: W. McNicholas, Dept of Respiratory Medicine, St. Vincent's University Hospital, Elm Park, Dublin 4, Ireland. Fax: 35 312697949. E-mail: walter.mcnicholas@ucd.ie 
the obstructive sleep apnoea/hypopnoea syndrome (OSAHS). In 1992, Guilleminault et al. [6] described a series of patients that had typical symptoms of OSAS but who did not have obstructive apnoeas or hypopnoeas on polysomnography. It was suggested that these events, characterised by increasing negative oesophageal pressure during inspiration and terminating with an arousal, reflected an upper airways resistance syndrome [6]. Central sleep apnoea is a much rarer form of sleep apnoea and may include particular forms of sleep apnoea such as CheyneStokes breathing and high altitude periodic breathing.

An important development in the definition of various sleep apnoea syndromes was the report of a Working Group of the American Academy of Sleep Medicine, which laid out the clinical criteria necessary for the diagnosis of a clinically significant sleep apnoea/hypopnoea syndrome and also proposed a grading of severity [7]. This report was co-sponsored by the ERS and the Society was represented in this working group by two members of the present Task Force (W.T. McNicholas and P. Levy). In the report, OSAHS requires that the individual must fulfil criterion 1 or 2, plus criterion 3. 1) Excessive daytime sleepiness that is not better explained by other factors. 2) Two or more of the following that are not better explained by other factors: choking or gasping during sleep; recurrent awakenings from sleep; unrefreshing sleep; daytime fatigue; impaired concentration. 3) Overnight monitoring demonstrates five or more obstructed breathing events per hour during sleep. These events may include any combination of obstructive apnoeas, hypopnoeas or respiratory effort-related arousals.

\section{Epidemiology and clinical aspects}

The International Classification of Sleep Disorders Manual contains codes (table 1) for a number of sleep-related breathing disorders. The wide variety of these disorders has only been recognised in recent years, as advances in diagnostic techniques led to improved clinical recognition and classification. OSAHS is the most prevalent of these disorders, affecting between $1-4 \%$ of adults $[1,8]$, and may be increasing in prevalence in association with an increasing prevalence of obesity and a sedentary lifestyle in Western society. As with most medical disorders, however, the majority of patients are likely to have a mild form of the disorder. Most of these cases are clinically unsuspected, since the two most common symptoms of loud snoring and a tendency to fall asleep during the daytime are often considered as normal variants, and patients frequently do not seek medical attention. Unfortunately, many patients who do seek medical attention are dismissed as having no significant illness without any formal assessment.

The failure to recognise clinically significant sleep apnoea is particularly unfortunate for a number of reasons. First, the condition carries a significant morbidity and mortality, and has been associated with an increased risk of hypertension, myocardial infarction and stroke, as discussed below, in addition to a significant risk of automobile accidents and injury in the workplace. Second, the condition is eminently treatable, and severe forms of the condition usually respond very well to the continued home use of nocturnal nasal continuous positive airway pressure (nCPAP). Patients with severe sleep apnoea frequently have an uncontrollable urge to fall asleep during the daytime, which is a natural consequence of the gross sleep disruption resulting from repeated apnoeas during sleep (usually several hundred per night). OSAHS represents the most common organic cause of excessive daytime sleepiness presenting to sleep disorders clinics. The prevalence of OSAHS is highest among males aged 40-59 yrs, being $~ 4-8 \%$, and is less common among females and those in the younger and older age groups.

There have been a considerable number of studies that have addressed the prevalence of OSAHS, and these are summarised in table 2 . One of the earliest such studies was that of LAVIE [9] in Israel, which estimated in a cross-sectional study that the prevalence of the syndrome among male industrial workers was at least $1 \%$. An Italian study of males aged $30-69$ yrs found a prevalence of $2.7 \%$ of OSA based

Table 1. - Sleep-related breathing disorders

\begin{tabular}{llc}
\hline Description & \multicolumn{1}{c}{ Synonyms } & ICD-9-CM code \\
\hline Obstructive sleep apnoea syndrome & Obesity hypoventilation syndrome & $780.53-0$ \\
Central sleep apnoea syndrome & Pickwickian syndrome & $780.51-0$ \\
Central alveolar hypoventilation syndrome & Nonobstructive sleep apnoea & $780.51-1$ \\
Primary snoring & Cheyne-Stokes respiration & $780.53-1$ \\
Infant sleep apnoea & Primary alveolar hypoventilation & \\
& Nonapnoeic alveolar hypoventialtion & 770.8 \\
Congenital central hypoventilation syndrome & Apnoea of prematurity & Apnoea of infancy \\
& Apparent life-threatening event & 770.81 \\
\hline
\end{tabular}

International classification of diseases (ICD)-9 and ICD-9-CM codes for a number of recognised sleep-related breathing disorders in the International Classification of Sleep Disorders Diagnostic and Coding Manual. ICD-9: World Health Organization: International Classification of Diseases, ninth edition; ICD-9-CM: North American Clinical Modification of ICD-9. 
Table 2. - Prevalence of obstructive sleep apnoea in various epidemiological studies

\begin{tabular}{|c|c|c|c|c|}
\hline $\begin{array}{l}\text { First author } \\
\text { [ref.no.] (country) }\end{array}$ & $\begin{array}{l}\text { Population } \\
\text { Subjects }\end{array}$ & Age yrs & Criteria & Prevalence $\%$ \\
\hline LAVIE [9] (Israel) & $1262 \mathrm{M}$ & $18-67$ & AI $>10$, symptomatic & $1.0-5.9$ \\
\hline TELAKIVI [10] (Finland) & $1939 \mathrm{M}$ & $30-69$ & Snoring, EDS and RDI $>10$ & $0.4-1.4$ \\
\hline GISLASON [11] (Sweden) & $3201 \mathrm{M}$ & $30-69$ & Snoring, EDS and AHI $>10$ & $0.7-1.9$ \\
\hline \multirow[t]{3}{*}{ CIRIGNOTTA [12] (Italy) } & $1170 \mathrm{M}$ & $30-39$ & $\mathrm{AI}>10$, symptomatic & $0.2-1.0$ \\
\hline & & $40-59$ & AI $>10$, symptomatic & $3.4-5.0$ \\
\hline & & $60-69$ & $\mathrm{AI}>10$, symptomatic & $0.5-1.1$ \\
\hline \multirow[t]{3}{*}{ STRADLING [13] (1991) } & 893 men & $35-65$ & $\mathrm{ODI}_{4}>20$, symptomatic & 0.3 \\
\hline & & & $\mathrm{ODI}_{4}>10$ & 1.0 \\
\hline & & & $\mathrm{ODI}_{4}>5$ & 4.6 \\
\hline \multirow[t]{2}{*}{ YoUNG [8] (USA) } & $352 \mathrm{M}$ & $30-60$ & Hypersomnia and RDI $>5$ & $4.0(\mathrm{M})$ \\
\hline & $250 \mathrm{~F}$ & $30-60$ & & $2.0(\mathrm{~F})$ \\
\hline GISLASON [14] (Iceland) & $2016 \mathrm{~F}$ & $40-59$ & $\begin{array}{l}\text { Habitual snoring, EDS and } \\
\text { verification of OSAS in PSG }\end{array}$ & $>2.5$ \\
\hline \multirow{3}{*}{$\begin{array}{l}\text { OLSON [15] } \\
\text { (Australia) }\end{array}$} & $1233 \mathrm{M}$ & $35-69$ & $\mathrm{AHI}>15$ & 4-18 \\
\hline & $969 \mathrm{~F}$ & & $\mathrm{AHI}>10$ & $7-35$ \\
\hline & & & $\mathrm{AHI}>5$ & $14-69$ \\
\hline \multirow{2}{*}{$\begin{array}{l}\text { BEARPARK [16] } \\
\text { (Australia) }\end{array}$} & $294 \mathrm{M}$ & $40-65$ & RDI $>10$ & 10.0 \\
\hline & & & Subjective EDS and RDI $>5$ & 3.0 \\
\hline GISLASON [17] (Iceland) & 555 Children & 6 months -6 yrs & $\begin{array}{l}\text { Habitual snoring or apneic } \\
\text { episodes, and } \mathrm{ODI}_{4}>3\end{array}$ & $>2.9$ \\
\hline \multirow[t]{2}{*}{ OHAYON [18] (UK) } & $2078 \mathrm{M}$ & $15-100$ & N/A & $2.4-4.6$ \\
\hline & $2894 \mathrm{~F}$ & $15-100$ & N/A & $0.8-2.2$ \\
\hline \multirow[t]{2}{*}{ KRIPKE [19] (USA) } & $165 \mathrm{M}$ & $40-64$ & $\mathrm{ODI}_{4}>20$ & $5.4-13.2$ \\
\hline & $190 \mathrm{~F}$ & $40-64$ & $\mathrm{ODI}_{4}>20$ & $2.1-8.3$ \\
\hline \multirow[t]{2}{*}{ BIXLER [20] (USA) } & $4364 \mathrm{M}$ & $20-100$ & $\begin{array}{l}\text { AHI }>10 \text { and clinical criteria } \\
\text { fulfilled with daytime symptoms }\end{array}$ & 3.3 \\
\hline & Subsample: 741 & & & 45-64 yrs: 4.7 \\
\hline \multirow[t]{2}{*}{ DURAN [21] (Spain) } & $1050 \mathrm{M}$ & $30-70$ & AHI $\geqslant 10$ & 19 \\
\hline & $1098 \mathrm{~F}$ & & & 15 \\
\hline
\end{tabular}

AI: apnoea index; EDS: excessive daytime sleepiness; RDI: respiratory disturbance index; AHI: apnoea/hypopnoea index; $\mathrm{ODI}_{4}$ : oxygen desaturations $>4 \%$ per hour; OSAS: obstructive sleep apnoea syndrome; PSG: polysomnography; N/A: not applicable; M: male; F: female.

on an apnoea/hypopnoea index (AHI) threshold of 10 and a history of snoring every night [12]. This estimate rose to between $3.5-5 \%$ among males aged $40-59$ yrs. BEARPARK et al. [16] reported a prevalence of $8.5 \%$ in Australia, but the data did not indicate how many patients were symptomatic.

One of the most comprehensive studies of OSAHS prevalence to date is the Wisconsin cohort study [7], which studied employed males and females aged 3060 yrs by means of full polysomnography. While $9 \%$ of females and $24 \%$ of males were found to have an apnoea index $(\mathrm{Al})>5 \cdot \mathrm{h}^{-1}$, this estimate of prevalence fell to $2 \%$ of females and $4 \%$ of males when an AI $>5$ was combined with symptomatic daytime sleepiness. These findings underline the importance of not viewing OSAHS in terms of AI or AHI alone. In the subgroup of patients aged $50-60 \mathrm{yrs}, 4 \%$ of females and $9 \%$ of males were found to have an $\mathrm{AI}>15$. In Spain [21] the prevalence of males having an AHI $>5$ was $15.3 \%$, and $9.1 \%$ had an AHI $>20$. Furthermore, $6.5 \%$ of the males met the minimal diagnostic criteria for OSAHS with an AHI $>5$ combined with daytime sleepiness. A recent study by BIXLER et al. [20] showed a mean prevalence of $3.3 \%$ among males aged 20 100 yrs. A peak prevalence of $4.7 \%$ (95\% confidence interval (CI): $3.1-7.1 \%$ ) was found among males aged 45-64 yrs. Among the 20-44-yr-olds and those aged $>65$ yrs the prevalence of OSAHS was $1.7 \%$.

\section{Sleep apnoea in the young and elderly}

Children may develop a sleep apnoea syndrome similar to that seen in adults and several epidemiological reports suggest a relatively high prevalence, although somewhat less than in adults. In an Italian study of 1,615 children aged 6-13 yrs [22], subjects were categorised according to whether they snored often, occasionally apart from with colds, only with colds, or never. A total 118 children $(7.3 \%)$ were habitual snorers, and rhinitic children were more than twice as likely to be habitual snorers (odds ratio (OR) 2.93) than others. There was also a positive correlation between parental smoking and the presence of snoring in children. In Iceland [17], $3.2 \%$ of 555 children aged 6 months to 6 yrs snored often or always during sleep. The estimated minimum prevalence of OSA in that age group was $2.9 \%$. The aetiology of OSAHS in children differs from adults in that adenotonsillar hypertrophy is the most common cause of OSAHS in infants and children [23], and can be cured by surgical removal.

It has long been recognised that sleep apnoeas are very common in the elderly. A total $19-24 \%$ of people aged $>65$ yrs have been reported to have more than five apnoeic events (AI >5) per hour of sleep in different epidemiological studies [24, 25]. In another 
study, $62 \%$ of elderly people had respiratory disturbance index (RDI) $\geqslant 10$ events $\cdot \mathrm{h}^{-1}$ [26]. However, the clinical significance of this high frequency of sleep apnoea among elderly people remains unclear. While many of these subjects are otherwise asymptomatic of sleep apnoea, there is evidence that sleep apnoea in the elderly has an adverse prognosis. BLIWISE et al. [27], who followed a cohort of 198 noninstitutionalised elderly individuals for up to 12 yrs after initial polysomnography found that the mortality ratio for those with sleep apnoea, defined as an RDI of $>10$ events per sleep hour, was 2.7 (95\% CI: 0.95-7.47). In a recent report, BIXLER et al. [20] emphasised the need for adjusting the criteria of OSAHS in elderly persons.

\section{Morbidity and mortality related to sleep apnoea syndrome}

The morbidity of OSAHS relates principally to the cardiovascular system. Compared to the general population, OSAHS patients appear to have at least twice as much hypertension, ischaemic heart disease and cerebrovascular disease [28-33]. However, this population of patients has a high incidence of other co-existing cardiovascular risk factors such as obesity, hyperlipidaemia, increased age, male sex, smoking history and excessive alcohol intake, which makes the identification of a clear independent association of OSAHS with cardiovascular disease more difficult [34]. Nonetheless, there is now convincing evidence from many studies of an independent association of OSAHS with hypertension [28-30] and this association has been reinforced by recent studies demonstrating a reduction in blood pressure levels with nCPAP therapy [30, 35]. Furthermore, a dose/response association between sleep-disordered breathing at baseline and the presence of hypertension 4-yrs later has been reported independently of known confounding factors [28]. In particular, the ORs for the presence of hypertension at follow-up were 1.42 with an AHI of $0.1-4.9 \cdot \mathrm{h}^{-1}$ at baseline compared with an AHI of zero, indicating that even minor degrees of sleep-disordered breathing may contribute independently to the development of hypertension.

A growing, but not yet conclusive, body of evidence points to an independent link between OSAHS and ischaemic heart disease $[31,32]$, cardiac dysrhythmias [36] and stroke [37-39]. Finally, there have been several studies examining mortality in OSAHS [40 42]. The mortality rates were evaluated at $\sim 6 \%$ per 5-8 yrs. Deaths attributed to vascular diseases and mortality rates were more apparent in subjects aged $<50$ yrs who had an 8-yr mortality rate of 10 versus $2 \%$ for older subjects [40]. LAVIE et al. [42] emphasised the importance of obesity and hypertension in the excess mortality found in the OSAHS clinic population. Although these studies have been criticised for their retrospective design, absence of control groups, and the use of AHI or AI as the only disease-defining variable, together they point to OSAHS as contributing to death in a middle-aged population.
Impact of treatment of obstructive sleep apnoeal hypopnoea on associated cardiovascular morbidity

Early studies evaluating the impact of treating OSAHS on cardiovascular morbidity have suffered from being of a suboptimal design, uncontrolled, not randomised or underpowered. However, two recent papers examined the effects of continuous positive airway pressure (CPAP) in normotensive OSAHS subjects through a randomised placebo-controlled trial and both demonstrated clear objective benefits of CPAP therapy on blood pressure (BP) levels [30, 35]. In one report, there was a small decrease in 24-h diastolic BP that was greater in the patients using their CPAP $>3.5 \mathrm{~h} \cdot$ night $^{-1}$ and those with $>20$ desaturation episodes per hour of sleep. The reduction in 24-h BP reached 4.0 and $5.0 \mathrm{mmHg}$, respectively for systolic and diastolic values in those patients with significant nocturnal intermittent hypoxia. The authors highlighted reports using conventional antihypertensive agents in non-OSAHS populations in whom a $5 \mathrm{mmHg}$ decrease in diastolic BP was associated with a $42 \%$ decrease in stroke and a $14 \%$ decrease in coronary heart disease within a 5-yr period [43]. Apart from hypertension, there are very limited data to support a significant impact of treatment on cardiovascular morbidity although one report has documented a beneficial impact on cardiac dysrhythmias [36].

\section{Association of sleep apnoea with road traffic accidents}

The principal daytime manifestation of OSAHS is sleepiness, which has long been recognised to be capable of adversely affecting awake functioning. The most serious potential consequence of sleepiness is impaired performance at the wheel while driving and there is now convincing evidence that sleepiness is a substantial risk factor for driving accidents. Estimates indicate that sleepiness causes over $20-25 \%$ of motorway accidents in the UK [44]. On the other hand, it has been shown that sleepiness is prevalent among drivers in general. From questionnaires distributed to 4,621 male UK drivers, $29 \%$ of them had felt close to falling asleep at the wheel in the last 12 months, and $9-10 \%$ had accidents related to tiredness [45]. Furthermore, $26 \%$ of US drivers had an Epworth Sleepiness Score $>10$ and $2 \%$ had a score $>15$ [46]. Among other causes of sleepiness while driving, sleep disorders such as narcolepsy and OSAHS are clearly important contributors and both disorders have been associated with an increased accident risk [47].

The relationship of OSAHS to road traffic accidents has been recognised for over a decade. FINDLEY et al. [48] in 1988 reported that patients with OSAHS had a seven-fold greater risk of road accidents than normals, and furthermore, the automobile accident rate of OSAHS patients was 2.6 times the rate of all licensed drivers in Virginia, USA. In addition, $24 \%$ of OSAHS patients reported falling asleep at least once per week while driving. In a community study of 1,001 males in England, STRAdLING et al. [49] found that regular snorers were significantly more likely to "almost have a car accident due to sleepiness" than others (OR 5.8). 
Young et al. [50], as part of the ongoing Wisconsin cohort study have reported that subjects with an AHI $>15 \cdot \mathrm{h}^{-1}$ have a substantially greater risk of motor vehicle accident than those with no sleep-disordered breathing (OR 7.3). BARBE et al. [51] in a prospective controlled study confirmed the increased risk of road accidents among 60 patients with OSAHS compared with a group of matched controls. In another Spanish study, Teran-Santos et al. [52] also found a substantial excess risk for driving accidents in patients with OSAHS. A total 102 drivers, admitted after an accident were compared to 152 controls randomly selected from primary care centres matched for sex, age and geographical location. All patients were screened with home respiratory polygraphy, complemented by confirmatory laboratory polysomnography as needed. The risk for having an accident was increased 6.3-fold (OR 95\% CI: 2.4-16.2) when comparing patients with AHI $<10$ versus those with AHI $>10$. Patients with OSAHS also perform worse in simulated driving situations than controls [53], and the performance on one of these simulated driving situations (Steer Clear) has been demonstrated to correlate with accident risk.

Accidents related to driver sleepiness are particularly likely to occur in the early morning or midafternoon and tend to be particularly serious because of the lack of reaction of the sleepy driver to the impending collision. Furthermore, sleepy drivers report a high incidence of near misses on the road while driving, which suggests that they have an awareness of the driving risks related to sleepiness short of being involved in an actual collision. There is also evidence that occupations such as long-haul truck driving are particularly associated with a risk of sleepiness while driving [54], and an increased risk of accident, particularly where there is evidence of associated OSAHS [55]. These findings may not be surprising given the relative sedentary and monotonous nature of this occupation, and the fact that longhaul truck drivers frequently drive for many hours at a time. These findings assume particular significance given the likelihood of a fatal accident where an articulated truck driven by a sleeping driver is involved. Many of the spectacular multiple vehicle collisions that have occurred on motorways throughout Europe have been ultimately traced to a driver falling asleep at the wheel.

Impact of treatment of obstructive sleep apnoeal hypopnoea syndrome on accident risk

A particularly important aspect of the relationship of OSAHS with accident risk is the potential impact of treatment. ENGLEMAN et al. [56] found that patients with OSAHS reported 0.93 sleep-related driving incidents (including accidents and near accidents) per 10,000 miles pre-CPAP and 0.14 after CPAP therapy was initiated. CASSEL et al. [57] also reported a similar reduction in accident rate in OSAHS patients after $1 \mathrm{yr}$ of nCPAP therapy, as have KRIEGER et al. [58]. A recent report by GEORGE [59] provides particularly convincing evidence of the benefits of CPAP therapy on accident risk. The study evaluated 210 patients with OSAHS treated with CPAP together with an equal number of randomly selected control drivers and evaluated motor vehicle collision (MVC) rates comparing the 3-yr period before and after CPAP therapy for patients and for the corresponding time frames in controls. They found an approximate three-fold increase in the frequency of MVCs in OSAHS patients before therapy compared with controls, but the MVC rate fell to similar levels as the control population in the 3 -yr period after instituting CPAP therapy.

The above data clearly identify OSAHS as a significant independent contributing factor to road traffic accidents with important consequences for public safety, particularly since accidents involving a patient with OSAHS are more likely to be associated with major injury. These considerations raise the question of the suitability of patients with OSAHS to hold a valid driving licence unless the condition is adequately treated. This question has previously been addressed by an ad hoc committee of the American Thoracic Society, which in their report [60] emphasised the difficulty in formulating rigid criteria to determine the suitability of a patient with OSAHS to hold a valid driver's licence. These difficulties are underlined by the widely accepted view that the diagnosis of OSAHS should not depend on a particular level of AHI alone, but should also take into account the degree of functional impairment associated with the condition, particularly sleepiness. The objective assessment of sleepiness by multiple sleep latency testing or maintenance of wakefulness testing (MWT) is cumbersome and not practical for widespread clinical use, which further complicates the issue of adequately assessing driving risk. However, a recently described simplified objective test of sleepiness may be useful in some settings [61]. While there are validated subjective measures of sleepiness such as the Epworth sleepiness scale [62] that are easy to administer, these measures are open to manipulation by a patient who does not wish to have their driving licence endorsed. Given the high prevalence of OSAHS and related breathing disorders during sleep in the general population, and the evidence that treatment decreases the risk of accidents in treated patients, it seems legitimate to try and reduce the occurrence of sleepiness-related accidents in affected patients by regulating the access to a driving license in those patients. In order to be able to inform sleep specialists as well as patients on the current regulations in European countries, the Task Force undertook a systematic inquiry to collect the relevant information.

\section{Driving regulations concerning sleep apnoea and/or excessive daytime sleepiness in different European countries}

\section{Methods}

As the Task Force developed the search, the search methods had to be adapted to the problems 
encountered. As a first step, the European Commission Directorate in charge of this problem was approached (Direction Générale (DG) 7, Unit B3) in Brussels, from which information concerning specific regulations in Belgium, Germany, Spain, and the Netherlands was obtained. It was then realised that this source of information was not fully reliable, as no information concerning the UK and Sweden, where there are specific regulations, were obtained. Thus sleep specialists from the different European countries were contacted via e-mail. Unfortunately, this source was not fully reliable either, as some colleagues ignored the regulations in their own country. Finally, a mixed strategy was used, where the national licensing authorities were approached, using the list of addresses obtained from colleagues and from the DG 7, and the official documents translated with the help of colleagues when the documents were not in English or French (S, NL, E, P, GR). Information from colleagues, when no answer was obtained, was also relied on (FIN, I).

During the initial search steps, the authors realised that beyond basic regulations on driving licensing and sleepiness, the ways in which the licensing authorities gathered information concerning the possible inability of a candidate to hold a driving license varied substantially from country to country, as did the frequency of inquiry, and the follow-up once an inability was detected. Therefore, in addition to requesting the official text of the driving regulations concerning sleepiness, a questionnaire addressing the questions shown in Appendix 1 was included, which was to be completed separately for Group 1 and Group 2 drivers.

\section{Results}

The questionnaires were sent out in December 1998. A reminder was sent out to nonresponders in September 1999, as well as an initial questionnaire to a new set of addresses, which were obtained in the meantime. A final reminder was sent out in May 2000 (see list of addresses in Appendix 2). Replies were collected February 1999-December 2000. All European Union (EU) National Licensing Authorities responded, except Italy and Finland, but not all completed the questionnaire (table 3). Only scarce information from non-EU European countries was obtained. The results are summarised in tables 3 and 4 for Group 1 drivers, and tables 5 and 6 for Group 2 drivers.

Definition of groups: Directive of the Council (29/07/91). In EU countries, driving licenses are specific to the vehicle driven, according to the following classes. A: motorcycles (A1 $<125 \mathrm{~cm}^{3}$ and $\left.11 \mathrm{~kW}\right)$; B: automobiles $<3,500 \mathrm{~kg},<8$ seats excluding driver (B1: tri and quadri motorcycles); C: automobiles $>3,500 \mathrm{~kg}(\mathrm{Cl}<7,500 \mathrm{~kg})$; D: $>8$ seats (D1 $<16$ seats); E: trailer $>750 \mathrm{~kg}$.

These classes are pooled into two groups: Group 1, which includes classes $\mathrm{A}, \mathrm{B}$ and $\mathrm{B}+\mathrm{E}$ (and $\mathrm{A} 1$ and $\mathrm{B} 1$ ) and Group 2, including classes C, C+E, D, D+E (and
$\mathrm{C} 1, \mathrm{C} 1+\mathrm{E}, \mathrm{D} 1, \mathrm{D} 1+\mathrm{E})$ and class $\mathrm{B}$ professional drivers (taxi, ambulance).

European Union countries. At the EU level, the common regulation is the Directive of the Council taken on July 291991 (Journal Officiel (JO) 24/08/91 No. L237/1-24), applicable since July 1 1996. Its Annex III lists disorders that are not compatible with driving. These disorders involve vision, audition, locomotion, cardiovascular system, diabetes, neurological and mental disorders, alcohol, drugs, renal, transplantation, but there is no mention of sleepiness or sleep apnoea.

The last paragraph (no. 18) of the Directive states that "as a general rule, a driving license should not be given or renewed to any candidate or license holder suffering from a disorder (not mentioned above) likely to compromise safety on the road, except if by authorised medical advice".

This regulation is applied as such in nine out of the 15 EU countries (AU, D, DK, FIN, GR, I, IRL, P). Five countries (B, E, F, S, UK) have specific regulations involving OSAHS or narcolepsy, in addition to idiopathic hypersomnia or insomnia. In the Netherlands, sleep disorders are included in a category of loss of consciousness other than epilepsy, and comprise narcolepsy as well as sleep apnoea. These regulations have been introduced recently between 1994 (NL) and 1998 (B, UK). The general rule is that the presence of the disorder contraindicates the acquisition and/or the maintenance of the driving license. In most cases, drivers or candidates are allowed to obtain or to keep their driving license only if they are effectively treated. This applies to Group 1 (tables 3 and 4) as well as to Group 2 (tables 5 and 6) drivers, but generally, the regulations are more restrictive for Group 2 drivers. In no case is effective treatment clearly defined, but in some countries the duration of effective treatment is specified, ranging from 1-6 months, with the exception of a requirement of 5 yrs without an "attack" applying to narcolepsy as well as to sleep apnoea (NL). Similarly, the frequency with which a treated driver requires re-evaluation varies from $1-3$ yrs.

Obviously, the efficacy of such regulations depends on the quality of the information available to the licensing authorities. In most countries, this is left to the sincerity of the license holder or applicant, who completes a form, which includes questions concerning sleep or sleepiness in a few countries $(B, U K)$. In some countries however, the license applicant must produce a medical certificate either systematically (DK, L, P), or only depending on the responses in the questionnaire (B), or even undergo a specific series of tests $(\mathrm{E})$. The frequency with which the procedure is repeated varies widely, from never to every 2 yrs (often depending on the driver's age and the license group).

Some specific situations worth mentioning. In the UK, an initial version of the document restricted the application of the regulation to "sleepiness leading to sudden and disabling event at wheel" but this was later changed to "excessive awake time sleepiness". OSAHS 
Table 3. - Existing regulations concerning Group 1 licences

\begin{tabular}{|c|c|c|c|c|c|c|c|c|c|c|}
\hline \multirow[t]{2}{*}{ Country } & \multirow[t]{2}{*}{ Regulations } & \multirow[t]{2}{*}{ Date } & \multicolumn{5}{|c|}{ Disorders } & \multicolumn{2}{|c|}{ Initial application } & \multirow[t]{2}{*}{ Repeated } \\
\hline & & & EDS & SAS & Narco & PLMS IH & Other & Driver & Doctor Other & \\
\hline \multicolumn{11}{|l|}{ EU } \\
\hline B & $\mathrm{Y}$ & $03 / 98$ & & + & + & & & $+\mathrm{QYC}^{\#}$ & $(+)^{\bullet}$ & \\
\hline $\mathrm{F}$ & Y & $05 / 97$ & + & + & + & + & & + QN & & \\
\hline GB & $\mathrm{Y}$ & 03/98 & + & + & + & & & $+\mathrm{QY}$ & & \\
\hline $\mathrm{E}$ & $\mathrm{Y}$ & $06 / 97$ & + & + & + & & $\begin{array}{l}\text { Insomnia } \\
\text { (hypnotics) } \\
\text { Circadian rhythm } \\
\text { disorders }\end{array}$ & & $+^{+}$ & $2 \mathrm{yr}$ \\
\hline $\begin{array}{l}\mathrm{S} \\
\mathrm{P} \\
\mathrm{AU}\end{array}$ & $\begin{array}{c}\mathrm{Y} \\
\mathrm{N}^{\# \#} \\
\mathrm{~N}^{\# \#}\end{array}$ & $06 / 96$ & + & + & + & & Ronchopathy & $\begin{array}{c}+\mathrm{QN} \\
+\mathrm{QNC}\end{array}$ & $+_{+}^{\S}$ & \\
\hline $\begin{array}{l}\text { DK } \\
\text { FIN }^{\S \S}\end{array}$ & $\mathrm{N}^{\# \#}$ & & & & & & & $+\mathrm{C}$ & & $>70$ \\
\hline $\mathrm{GR}^{f f}$ & $\mathrm{~N}^{\# \#}$ & & & & & & & & & \\
\hline $\mathrm{IRL}^{++}$ & $\mathrm{N}$ & & & & & & & & & \\
\hline $\mathrm{L}$ & $\mathrm{N}$ & & & & & & & $+\mathrm{C}$ & & $\begin{array}{l}\text { At age } 50,60, \\
70, \text { then every } \\
3 \text { yrs after } \\
70 \text { yrs, every } \\
\text { year after } 80 \text { yrs }\end{array}$ \\
\hline $\mathrm{NL}^{++}$ & $\mathrm{Y} / \mathrm{N}$ & 1994 & & & & & $\begin{array}{l}\text { Disturbances of } \\
\text { consciousness } \\
\text { other than } \\
\text { epilepsyff }\end{array}$ & $+\mathrm{QN}$ & & $\begin{array}{l}\text { Not until } \\
70 \mathrm{yrs}\end{array}$ \\
\hline \multicolumn{11}{|l|}{$\mathrm{D}^{++}$} \\
\hline $\mathrm{N}$ & $\mathrm{N}^{\# \#}$ & & & & & & & $+\mathrm{QN}^{\oplus \uparrow}$ & $+\pi$ & No \\
\hline $\mathrm{CH}$ & $\mathrm{N}^{\# \#}$ & & & & & & & QN & $+^{f}$ & $>70: 2 \mathrm{yr}$ \\
\hline
\end{tabular}

EU: countries belonging to the European Union; Non-EU: not belonging to the EU; EDS: excessive daytime sleepiness; SAS: sleep apnoea syndrome; Narco: narcolepsy; PLMS: periodic leg movement syndrome; IH: idiopathic hypersomnolence; Y: yes; N: no; C: certificate; Q: questionnaire; QY: the questionnaire includes question(s) concerning EDS; QN: questionnaire includes no question concerning EDS; B: Belgium; F: France; UK: United Kingdom; E: Spain; S: Sweden; P: Portugal; AU: Austria; DK: Denmark; Fin: Finland; GR: Greece; I: Italy; IRL: Ireland; L: Luxembourg; NL: Netherlands; D: Germany; N: Norway; CH: Switzerland. \#: if applicant cannot complete all items in the questionnaire; ": only if driver is a danger to themself or others; ${ }^{+}$: medical centre specific for driver evaluation; ${ }^{\S}$ : mandatory disclosure; ${ }^{f}$ : any doctor is allowed to report any disorder which may constitute a public hazard; ${ }^{\#}$ : general rule, medical conditions that impair the ability to drive safely; बः: physician act and road traffic act obligate physicians (and license holders) to report to the county medical officer; ++ responded, but did not complete the questionnaire; ${ }^{\$ \S}$ : did not respond; ${ }^{f f}$ : includes syncope, narcoleptic episodes, cataplectic attacks, and SAS.

is not specifically mentioned, but "sleep disorders" appear in the section on Respiratory Disorders.

In Sweden, a medical certificate is mandatory to apply for a driving license and is usually completed by the general practitioner. This must be renewed after the age of 65 yrs for C, D, E license holders, which therefore indicates that the physician decides whether a patient is fit to drive.

In Spain, a psychotechnical examination is performed by a private office accredited by licensing authorities, at the first application, then every $10 \mathrm{yrs}$ before the age of $45 \mathrm{yrs}$, every 5 yrs until the age of $60 \mathrm{yrs}$, every 3 yrs until an age of $70 \mathrm{yrs}$, then yearly. The examination includes a test on a driving simulator in addition to sight, hearing and BP testing. A questionnaire on general health includes medication taken and possible sleepiness. If any abnormality is detected, a report to the licensing authorities is made and the candidate is referred to a Sleep Centre.
In Belgium, a questionnaire is completed on the initial application for a license. If, at a later date, OSAHS is diagnosed, the driver must send their license to the licensing authority, but may get it back when able to provide a medical certificate stating that they are adequately treated.

In Germany, there is no mention of sleepiness in the law concerning disabilities incompatible with a driving license, but under the general rule that any driver should be fit, recommendations were issued by the Ministry of Traffic stating that sleepy OSAHS drivers should not be allowed to drive and specify criteria for adequate treatment for Group 2 drivers.

In Italy, although a formal response from the National Licensing Authorities was not obtained, direct information indicated that there are no specific regulations concerning OSAHS, i.e. the general rule concerning fitness to drive applies. 
Table 4. - Group 1 licences (continued)

\begin{tabular}{|c|c|c|c|c|c|c|c|c|c|c|c|c|c|c|}
\hline \multirow[t]{2}{*}{ Country } & \multicolumn{5}{|c|}{ After license } & \multicolumn{6}{|c|}{ Further information } & \multicolumn{3}{|c|}{ License Returned after Tx } \\
\hline & Driver & Doctor & Police & Court & Other & Driver & Report Dr & Question Dr & $\begin{array}{c}\text { Sleep } \\
\text { specialist }\end{array}$ & $\begin{array}{c}\text { Other } \\
\text { specialist }\end{array}$ & Other & & $\begin{array}{c}\text { Tx } \\
\text { efficacy }\end{array}$ & Fw-up \\
\hline \multicolumn{15}{|l|}{ EU } \\
\hline $\mathrm{B}$ & + & + & & & & & + & & & $\mathrm{Neu}$ & & $\mathrm{Y}$ & $\mathrm{Y}^{\#}$ & $2 \mathrm{yr}^{\circ}$ \\
\hline $\mathrm{F}$ & + & & + & + & + préfet & + & & & & & $+^{+}$ & $\mathrm{Y}$ & $\mathrm{N}$ & $\mathrm{V}$ \\
\hline GB & + & + & + & + & & + & & + & & & & $\mathrm{Y}$ & $\mathrm{N}$ & $\mathrm{N}$ \\
\hline $\mathrm{E}$ & & + & + & + & & & & & + & & & $\mathrm{Y}$ & $\mathrm{N}$ & $2 \mathrm{yr}$ \\
\hline $\mathrm{S}$ & & $+^{++}$ & + & & & & + & & + & & & $\mathrm{Y}$ & $\mathrm{N}$ & $\mathrm{V}$ \\
\hline $\mathrm{P}$ & + & + & + & + & Adminis & & & & + & $\mathrm{Neu}$ & & $\mathrm{Y}$ & $\mathrm{N}$ & $1 \mathrm{yr}$ \\
\hline $\mathrm{AU}$ & & & + & + & & & + & & + & & & & & \\
\hline DK & & $+^{f}$ & + & + & & & + & & & & & & & \\
\hline \multicolumn{15}{|l|}{ FIN } \\
\hline \multicolumn{15}{|l|}{ GR } \\
\hline \multicolumn{15}{|l|}{ I } \\
\hline IRL & & & & & & & & & & & & $\mathrm{Y}$ & $\mathrm{N}$ & \\
\hline $\mathrm{L}$ & $+\mathrm{C}$ & $+\mathrm{C}$ & + & & & + & & & + & & & $\mathrm{N}$ & & \\
\hline NL & & & & & & & & & & $\mathrm{Neu}^{\S}$ & & $\mathrm{Y}^{\S}$ & $\mathrm{Y}^{\S}$ & $1 \mathrm{yr}^{\S}$ \\
\hline \multicolumn{15}{|l|}{$\mathrm{D}$} \\
\hline \multicolumn{15}{|l|}{ Non-EU } \\
\hline $\mathrm{N}$ & $+{ }^{\# \#}$ & $+{ }^{\# \#}$ & & & & + & + & & + & & & & $\mathrm{N}$ & \\
\hline $\mathrm{CH}$ & & $+\oplus$ & + & & & + & + & & + & & & $\mathrm{Y}$ & $\mathrm{N}$ & $1 \mathrm{yr}$ \\
\hline $\begin{array}{l}\text { Tx: treatr } \\
\text { Fin: Finl } \\
\text { sleep apn } \\
\text { by the Li } \\
\text { road traf } \\
\text { hazard; }\end{array}$ & $\begin{array}{l}\text { it; Fw-u } \\
\text {; GR: } \\
\text { syndro } \\
\text { sing Au } \\
\text { act obliq } \\
\text { nandate }\end{array}$ & $\begin{array}{l}\text { follow-u } \\
\text { ece; I: It } \\
\text { (SAS) } 1 \\
\text { rity (fro } \\
\text { e physici } \\
\text { disclosu }\end{array}$ & $\begin{array}{l}\text { V: vari } \\
\text {; IRL: } \\
\text { lonth af } \\
\text { a list an } \\
\text { s (and l }\end{array}$ & $\begin{array}{l}\text { le; Neu } \\
\text { eland; } \\
\text { r efficie } \\
\text { ng gene } \\
\text { ense ho }\end{array}$ & $\begin{array}{l}\text { eurologis } \\
\text { Luxembo } \\
\text { Tx startec } \\
\text { l practitio } \\
\text { ers) to rep }\end{array}$ & $\begin{array}{l}\text { B: Belgit } \\
\text { g; NL: } \\
\text { : narco } \\
\text { rs and/o } \\
\text { t to the }\end{array}$ & $\begin{array}{l}\text {; F: France; } \\
\text { therlands; D } \\
\text { osy, 2-yr max } \\
\text { pecialists); } \\
\text { unty medica }\end{array}$ & $\begin{array}{l}\text { JK: United Ki } \\
\text { Germany; N: } \\
\text { SAS } 2 \text { yr once } \\
\text { or the case of re } \\
\text { officer; }{ }^{\uparrow} \text { : any }\end{array}$ & $\begin{array}{l}\text { dom; E: } \mathrm{S} \\
\text { orway; CH } \\
\text { ithout limi } \\
\text { orted loss c } \\
\text { octor is all }\end{array}$ & $\begin{array}{l}\text { in; S: Swe } \\
\text { Switzerlan } \\
\text { tion if nor } \\
\text { consciousr } \\
\text { yed to rep }\end{array}$ & $\begin{array}{l}\text { n; P: Pc } \\
\text { \#: narc } \\
\text { al after } \\
\text { s; }{ }^{f}: \text { inf } \\
\text { any di }\end{array}$ & $\begin{array}{l}\text { gal; } \\
\text { sy, } 6 \\
;+ \text { : } \\
\text { is the } \\
\text { ler w }\end{array}$ & 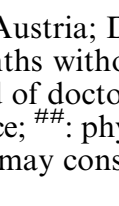 & $\begin{array}{l}\text { enmark } \\
\text { mptoms } \\
\text { ppointed } \\
\text { n act and } \\
\text { a public }\end{array}$ \\
\hline
\end{tabular}


Table 5. - Existing regulations concerning Group 2 licences

\begin{tabular}{|c|c|c|c|c|c|c|c|c|c|c|c|c|}
\hline \multirow[t]{2}{*}{ Country } & \multirow[t]{2}{*}{ Regulations } & \multirow[t]{2}{*}{ Date } & \multicolumn{6}{|c|}{ Disorders } & \multicolumn{3}{|c|}{ Initial application } & \multirow[t]{2}{*}{ Repeated } \\
\hline & & & EDS & SAS & Narco & PLMS & IH & Other & Driver & Doctor & Other & \\
\hline \multicolumn{13}{|l|}{ EU } \\
\hline B & Y & 03/98 & & + & + & & & & $+\mathrm{QY} \mathrm{C}$ & $(+)^{\#}$ & + & $5 \mathrm{yr}$ \\
\hline $\mathrm{F}$ & Y & $05 / 97$ & + & + & + & & + & & + QN & $+^{+}$ & & $5 \mathrm{yr}$ \\
\hline GB & Y & $03 / 98$ & + & & & & & & $+\mathrm{QY}$ & & & \\
\hline $\mathrm{E}$ & $\mathrm{Y}$ & $06 / 97$ & + & + & + & & + & $\begin{array}{l}\text { Insomnia } \\
\text { (hypnotics) } \\
\text { Circadian } \\
\text { rhythm } \\
\text { disorders }\end{array}$ & & + & & $1 \mathrm{yr}$ \\
\hline $\begin{array}{l}\mathrm{S} \\
\mathrm{P} \\
\mathrm{AU}\end{array}$ & $\begin{array}{l}\mathrm{Y} \\
\mathrm{N}^{f} \\
\mathrm{~N}^{f}\end{array}$ & $06 / 96$ & + & + & + & & & Ronchopathy & $\begin{aligned} & \text { QN C } \\
+ & \text { QN C }\end{aligned}$ & $++^{6 \mathrm{~b}}$ & & $10 \mathrm{yr}^{\bullet \oplus}$ \\
\hline $\begin{array}{l}\text { DK } \\
\text { FIN } \\
\text { GR } \\
\text { I } \\
\text { IRL }\end{array}$ & $\mathrm{N}^{f}$ & & & & & & & & $+\mathrm{C}$ & & & $5 \mathrm{yr}$ \\
\hline $\mathrm{L}$ & $\mathrm{N}$ & & & & & & & & $+\mathrm{C}$ & & & $\begin{array}{c}10 \text { yr before } \\
\text { age } 50 \text { yrs } \\
5 \mathrm{yr} \text { after } \\
\text { age } 50 \mathrm{yrs}\end{array}$ \\
\hline NL & $\mathrm{Y} / \mathrm{N}$ & 1994 & & & & & & $\begin{array}{l}\text { Disturbances of } \\
\text { consciousness } \\
\text { other than } \\
\text { epilepsy }\end{array}$ & $+\mathrm{QN}$ & + & & $\begin{array}{l}\text { Not until } \\
70 \text { yrs }\end{array}$ \\
\hline $\begin{array}{c}\text { D } \\
\text { Non-EU }\end{array}$ & & & & & & & & & & & & \\
\hline $\begin{array}{l}\mathrm{N} \\
\mathrm{CH}\end{array}$ & $\begin{array}{l}\mathbf{N}^{f} \\
\mathbf{N}^{f}\end{array}$ & & & & & & & & $\stackrel{+{ }^{\# \#}}{\mathrm{C}^{++}}$ & $++^{\# \#}$ & & $\begin{array}{l}10 \mathrm{yr} \\
<50: 5 \mathrm{yr} \\
>50: 3 \mathrm{yrs}\end{array}$ \\
\hline
\end{tabular}

EU: countries belonging to the European Union; Non-EU: not belonging to the EU; EDS: excessive daytime sleepiness; SAS: sleep apnoea syndrome; Narco: narcolepsy; PLMS: periodic leg movement syndrome; IH: idiopathic hypersomnolence; Y: yes; N: no; C: certificate; Q: questionnaire; QY: the questionnaire includes question(s) concerning; EDS; QN: questionnaire includes no question concerning EDS; B: Belgium; F: France; UK: United Kingdom; E: Spain; S: Sweden; P: Portugal; AU: Austria; DK: Denmark; Fin: Finland; Gr: Greece; I: Italy; Irl: Ireland; L: Luxembourg; NL: Netherlands; D: Germany; N: Norway; CH: Switzerland. ${ }^{\#}$ : only if driver is a danger for himself or others; ' : medical centre specific for driver evaluation (or restrictive list of authorised doctors in Belgium); ${ }^{\circledR}$ : any doctor is allowed to report any disorder which may constitute a public hazard; ${ }^{f}$ : general rule, medical conditions that impair the ability to drive safely; ${ }^{\# \#}$ : physician act and road traffic act obligate physicians (and license holders) to report to the county medical officer; ${ }^{\circledR}$ : after ages of $45 \mathrm{yrs}$, from a special district doctor; $\$ \$$ : includes syncope, narcoleptic episodes, cataplectic attacks, and sleep apnoea syndrome.

Non-European Union countries. Answers were obtained from Norway and Switzerland only (see tables 3-6). In Switzerland, doctors are allowed to report a sleepy driver to the vehicle licensing authority. Federal law authorises (but does not force) a physician to report any individual judged to be medically unable to drive to the authorities.

Comment. During the collection of data, a regular comment from medical respondents was that OSAHS patients are more dangerous before they have been diagnosed than after they have been commenced on treatment. Therefore, they felt that the law by itself would be insufficient to reduce the risk related to disorders causing sleepiness. The sleep disorders mentioned in the law represent only a minority of the causes of sleepiness while driving. Therefore, they felt it was unfair to penalise patients who in addition may be better informed, and thus more cautious, than the occasionally sleepy "normal" driver. The threat of withdrawing the license was used as a tool by some clinicians to motivate patients towards accepting treatment such as CPAP.

\section{Recommendations concerning driver licensing}

The data generated in the present survey make clear that there are no uniformly accepted regulations within Europe concerning driving licensing and OSAHS, and indeed many national European licensing authorities make no specific mention of sleep apnoea. These deficiencies underline the importance of adequate measures being taken and regulations put in place to protect both the patient with OSAHS and the wider community from death or injury related to road traffic accidents caused by sleepy drivers with untreated OSAHS. Any such regulations concerning driver licensing in OSAHS must be based on a definition of the condition that relates to likely driving 
Table 6. - Group 2 licences (continued)

\begin{tabular}{|c|c|c|c|c|c|c|c|c|c|c|c|c|c|c|}
\hline \multirow[t]{2}{*}{ Country } & \multicolumn{5}{|c|}{ After license } & \multicolumn{6}{|c|}{ Further info } & \multicolumn{3}{|c|}{ License Returned after Tx } \\
\hline & Driver & Doctor & Police & Court & Other & Driver & Report Dr & Question Dr & $\begin{array}{c}\text { Sleep } \\
\text { specialist }\end{array}$ & $\begin{array}{c}\text { Other } \\
\text { specialist }\end{array}$ & Other & & $\begin{array}{c}\text { Tx } \\
\text { efficacy }\end{array}$ & Fw-up \\
\hline \multicolumn{15}{|l|}{ EU } \\
\hline $\mathrm{B}$ & + & $+{ }^{\#}$ & & & & + & + & + & + & Neu Pneumo & & $\mathrm{Y}^{\oplus}$ & $\mathrm{Y}^{+}$ & $1 \mathrm{yr}^{\S}$ \\
\hline $\mathrm{F}$ & + & & + & + & + préfet & + & & & & & $+^{f}$ & $\mathrm{Y}$ & $\mathrm{N}$ & $\mathrm{V}$ \\
\hline GB & + & $(+)$ & $(+)$ & $(+)$ & & + & & + & & & & $\mathrm{Y}^{\# \#}$ & $\mathrm{~N}$ & $1 \mathrm{yr}$ \\
\hline $\mathrm{E}$ & & + & + & + & & & & & + & & & $\mathrm{Y}$ & $\mathrm{N}$ & $1 \mathrm{yr}$ \\
\hline $\mathrm{S}$ & & + & + & & & & + & & + & & & $\mathrm{Y}$ & $\mathrm{N}$ & $\mathrm{V}$ \\
\hline $\mathrm{P}$ & + & + & + & + & Admin & & & & + & $\mathrm{Neu}$ & & $\mathrm{Y}$ & $\mathrm{N}$ & $1 \mathrm{yr}$ \\
\hline $\mathrm{AU}$ & & & + & + & & & + & & + & & & & & \\
\hline DK & & $+\pi$ & + & + & & & + & & & & & & & \\
\hline \multicolumn{15}{|l|}{ FIN } \\
\hline \multicolumn{15}{|l|}{ GR } \\
\hline \multicolumn{15}{|l|}{ I } \\
\hline \multicolumn{15}{|l|}{ IRL } \\
\hline $\mathrm{L}$ & $+\mathrm{C}$ & $+\mathrm{C}$ & + & & & + & & & + & & & Y ? & $\mathrm{N}$ & $?$ \\
\hline $\mathrm{NL}$ & & & & & & & & & & $\mathrm{Neu}^{++}$ & & $\mathrm{Y}^{++}$ & $\mathrm{Y}^{++}$ & $5 \mathrm{yr}^{++}$ \\
\hline \multicolumn{15}{|l|}{$\mathrm{D}$} \\
\hline \multicolumn{15}{|l|}{ Non-EU } \\
\hline $\mathrm{N}$ & $+^{\S \S}$ & $++^{\S \S}$ & & & & + & + & & + & & & & $\mathrm{N}$ & \\
\hline $\mathrm{CH}$ & & + & + & & & + & + & & + & & & & $\mathrm{N}$ & $1 \mathrm{yr}$ \\
\hline
\end{tabular}


risk rather than some arbitrary AHI level. Particular attention needs to be given to certain high-risk driver occupations such as commercial long-haul truck drivers. Furthermore, given the fact that such a definition should include some measure of sleepiness, care must be taken that unrealistic demands are not made on either the sleep disorders centre that establishes the diagnosis of OSAHS or on the primary physician responsible for the patient's management to determine an individual patient's suitability to hold a valid driving licence. While such a decision would be unlikely to present difficulties in patients with severe OSAHS, this may not be the case in many patients with mild-to-moderate disease, where moderately high AHI levels may not be associated with significant levels of sleepiness and vice versa. These considerations indicate that education of those concerned with implementing driving license policy to produce a greater level of awareness of the problem would be more important and likely to be more successful than arbitrary regulations dictating licensing policy based on certain subjective or objective criteria of either sleep apnoea or sleepiness.

Regulations concerning driver licensing in OSAHS should include a shared responsibility between the physician, patient and licensing authority. A distinction can be drawn between private and professional drivers, and it seems appropriate that more strict regulations should be applied to the professional driver because of the increased risk to the general public from sleepiness in this category of driver. Given the high prevalence of OSAHS in Europe, public health and safety make it imperative that practical and realistic guidelines be implemented, preferably on a Europe-wide basis to ensure that patients with OSAHS who present a driving risk are precluded from driving unless given adequate treatment for their condition.

Specific regulations for licensing that would exclude sleepy subjects from access to a driving license pose many questions. Philosophically, the choice is between individual freedom and the protection of society against a potential risk. This choice of society has been handled in different ways in different countries, but obviously the debate is still open in many places. Morally, such regulations pose the question of how licensing authorities will obtain the relevant information. The choice is between relying on the driver's honesty, which is open to cheating, or on a third party, usually a doctor, to provide a certificate of medical competence. In this regard, it may be difficult for the patient's own physician to provide a negative certificate or for an external doctor to gather the relevant information. Economic considerations indicate that the cost of sleepiness-related accidents should be compared to the cost of unemployment/decreased quality of life due to the loss of a driving license, but such comparisons have never been made.

Ethically, the dilemma of driver certification in OSAHS poses the question of medical power versus medical responsibility. Clearly, specific regulations might give doctors the power to prevent sleepy drivers from driving, which might enhance the general recognition of Sleep Medicine and of Sleep Centres.
However, the criteria that could be used to decide a driver's medical fitness before or, even more so, after treatment are not yet clearly established, particularly in view of the difficulties in the objective evaluation of sleepiness. Furthermore, the reality is that the diagnosis of OSAHS is usually made after months or years of sleepy driving, and often after an accident (or a near-miss). Therefore, education of nonspecialised doctors and the general population in the recognition of the disorder would appear to be at least as important as issuing specific regulations. It also poses the question of the confidence between patients and doctors. The risk exists that if the doctor is allowed to report a given patient to the licensing authorities, patients will be tempted to hide their symptoms and not go to the doctor. One could argue that it is better to treat a confident patient without declaring the disorder to the authorities than to deal with a suspicious and uncooperative patient.

Finally, from the practical point of view, it appears that education and information of the professionals involved in road safety plays a critical role. Having specific regulations concerning sleepy drivers would be meaningless if police and other law officers are not aware of the details. All sleep specialists have seen patients who have had car accidents due to falling asleep at the wheel in which the police, and sometimes the court, have taken legal measures against the offender but have failed to recommend medical intervention. While it is far from clear that specific regulations concerning sleepiness and driving are effective in reducing road accidents related to OSAHS, such specific regulations, where applied, deserve further evaluation and update. This is particularly so since there are no objective data on the prevalence of sleepiness-related accidents from those countries that have introduced such regulations. However, whatever the legislation, the clinician has a responsibility to inform his patient of the risks related to sleepiness, and to discourage him from driving as long as he is not effectively treated. In some countries, it may also be the doctor's responsibility to inform the licensing authorities.

\section{Association of sleep apnoea with other forms of accidents}

The evidence of association between sleepiness and other forms of accidents, particularly industrial accidents, is limited. In a questionnaire survey, KRIEGER et al. [58] demonstrated a higher frequency of domestic and occupational accidents in patients with OSAHS compared to the general French population and a reduction in the accident rate following introduction of CPAP therapy. A more recent 10-yr prospective population study by LindBERG et al. [63] reported a significantly higher risk of industrial accidents (OR 2.2) among snorers who also reported excessive daytime sleepiness compared to subjects who were neither sleepy nor snored. These data strongly suggest an association between OSAHS and industrial accident risk similar to that seen with driving accidents but further work is 
needed in this area to more clearly establish the types of occupation that are most at risk.

\section{Resource implications for the investigation and management of sleep apnoea syndrome}

Measures to reduce the impact of OSAHS and the related driver sleepiness on road traffic accidents have little meaning if there are inadequate facilities available to investigate and manage patients with the disorder. Such facilities are inadequate in most countries throughout Europe, which reflects the high prevalence of the disorder and also the fact that OSAHS is a relatively recently recognised clinical problem. Thus, hospital administrators and clinicians from other disciplines may not recognise the importance of providing appropriate facilities for the practice of sleep medicine. Even many sleep specialists have been surprised at the high prevalence of the disorder and most clinical sleep centres have long waiting lists of patients awaiting investigation and/or treatment. Current epidemiological data indicate that there are likely to be at least 5 million patients suffering from OSAHS throughout Europe, and this disorder is second only to asthma in the prevalence league table of chronic respiratory disorders. Thus, the provision of appropriate clinical facilities to investigate and manage these patients represents a major challenge for the Health Services in each European state.

While it may be understandable that healthcare providers in some countries are hesitant to commit substantial resources to the investigation and management of patients with OSAHS, such hesitancy is inappropriate for a number of reasons. First, the cost of investigation of these patients compares favourably with the costs of investigation in many other medical specialties such as the cost of endoscopy in gastrointestinal disorders. This is particularly so where ambulatory sleep studies are performed. The cost of nCPAP therapy principally relates to the one-off cost of the CPAP device, which compares very favourably with the ongoing cost of inhaled therapy in chronic asthma. Second, the benefits of CPAP therapy in OSAHS are now clearly established in terms of improved quality of life, personal and public safety, and more recently, reduced morbidity. While there are few validated figures available, there appears little doubt that in straight financial terms, the economic benefit in terms of increased productivity, reduced accident risk, and reduced healthcare utilisation from related morbidity would substantially outweigh the economic cost of investigating and treating the disorder.

A recent position statement of the American Academy of Sleep Medicine [64] unequivocally supports the cost justification for diagnosis and treatment of OSAHS, particularly the cost benefit of sleep monitoring in the diagnosis. There is evidence that prior to diagnosis, patients with OSAHS incur higher healthcare costs than matched control subjects [6568]. RonALD et al. [65] reported that OSAHS patients used more than twice as many healthcare services in the $10-y r$ period prior to diagnosis compared to controls, and the excess cost compared with control subjects was in the region of 4,265 Canadian dollars per patient. Furthermore, the same group reported a significant reduction in healthcare costs in the $2-y r$ period after introduction of CPAP therapy compared to the 5-yr period before diagnosis and also compared to matched controls during the same $7-\mathrm{yr}$ period of follow-up [67]. KAPUR et al. [68] reported an annual healthcare utilisation cost of US $\$ 2,720$ for OSAHS patients prior to diagnosis compared to US $\$ 1,384$ among matched control subjects.

It is clear from the foregoing discussion that much remains to be done to educate healthcare workers, health administrators, and politicians on the importance of disorders such as obstructive sleep apnoea/ hypopnoea syndrome and the practical value in providing the resources needed to adequately manage the disorder in Europe. The European Respiratory Society has an important role to play in this endeavour, particularly at a pan-European level. This aspect of respiratory medicine appears ideally suited to a targeted approach to the European Commission, which has identified public health as a key area for attention in the coming years.

\section{Appendix 1: Questionnaire sent to National Licensing Authorities}

1) In your country, are there regulations requiring sleepy drivers to be reported to the Vehicle Licensing Authorities or some other statutory body (please name):

Yes: $\square$ No: $\square$ When were these regulations introduced?: . . . . . . . . . . . . . . . .

If so, what are these regulations?: (Please include a copy of the corresponding text)

To which sleep disorders do they apply?:

Sleepiness without further specification:

Sleep apnoea:

Periodic leg movements:

Narcolepsy:

Idiopathic hypersomnia:

Other:

Please specify:. . . . . . . . . . . .

2) Who must report the sleepy driver (or more generally a disability) to the authorities

a) at the time of initial application for licensing? Driver $\square$

if so, by which means? Questionnaire: $\square$

if so, does the questionnaire include questions on sleepiness?

Yes: $\square$ No:

Medical certificate (established at the applicant's request): 
if so, which doctor must provide

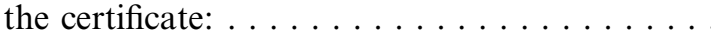

Doctor $\square$ (without the driver's approval) if so, by what means?: . . . . . . . . .

Other $\square$ (please specify). . . . . . . . . . . . .

b) is the initial procedure of detection of disability repeated periodically?

if so, how often?: . . . . . . . . . . . . . .

c) when a disability is identified in a licensed driver, who must report to the authorities?

Driver $\square$ if so, by which means: . . . . . . .

Doctor $\square$ (without the driver's approval) if so, by which means: ...........

Police $\square$ (when an incident related to sleepiness occurs)

Court $\square$ (when an incident related to sleepiness occurs)

Other $\square$ (please specify) . . . . . . . . . . .

3) Once the individual has been reported, how is further information obtained upon which a decision is made about the suitability of driving:

Personal report from driver:

Report from driver's doctor:

Questionnaire from driver's doctor:

Report from sleep specialist:

Report from other specialist:

which specialist?:

Other: $\square$ please specify: . . . . . . . . . . . . . . . .

If the treatment of a sleep disorder allows the return of driving license, are there legal conditions for the efficacy of treatment?

Yes: $\square$ No: $\square$

If so which ones?: . . . . . . . . . . . . . .

Does treatment efficacy need to be regularly re-established?

If so how often?:. . . . . . . . . . . . .

\section{Appendix 2: Initial set of addresses of National Licensing Authorities}

\section{European Union countries}

Austria: Bundesministerium für Inneres

Herreng 7

A-1010 Wien

Belgium: Belgisch Instituut voor Verkeersveiligheid Haachtsesteenweg 1405

B-1130 Brussels

Finland: Vehicle Administration Center (Ajoneuvohallintokeskus)

Driving licence group (Ajokorttiryhmä)

P.O.Box 120

FIN-00101 Helsinki

France: Ministère des transports

Direction de la Sécurité et de la Circulation Routière

Service des permis de Conduire

Arche de la Défense - Paroi Sud

F-92055 PARIS LA DEFENSE CEDEX 0
Germany: Bundesministerium für Verkehr

Robert-Schumann-Platz 1

D-53175 Bonn

Luxembourg: Service des Permis de Conduire

19-21blv. Royal

L-2938 Luxembourg

Portugal: Direcção-Geral de Viação

Gabinete de Informação e Relações Internacionais

Av. da República 16, $9^{\circ}$

P-1050 Lisboa

Direcção de Serviços de Condutores e Veículos (drivers and vehicles services)

Av. da República 16, $5^{\circ}$

P-1050 Lisboa

Direcção de Serviços Circulação e Segurança Rodoviária (traffic and road safety services)

Adress: Av. da República 16, $6^{\circ}$

P-1050 Lisboa

Spain: Dirección General de Tráfico

Dpto. de Formación Vial

Josefa Valcarcel 28

E-Madrid

Sweden: Trafikenheten

Ldnsstyrelsen

Box 22067

S-104 22 Stockholm

Kvrkortsmyndigheten

Vdgverket

S-781 87 Borldnge

United Kingdom: DVLC

Swansea

Drivers Medical Branch

GB-SA1 1TU Swansea

Non-European Union countries

Czech: Ministry of Internal affairs, street M. Horakove CZ-17000 Prague 7

Iceland: Umferdarrad

Borgartuni 33

150 Reykjavik

Iceland

Norway: Statens Helsetilsyn

P.O. Box 8128 Dep.

N-0032 Oslo

Slovakia: Emniyet Genel Müdürlüðü

Sekcija za medicino dela

ZZD Slovensko Zdravni\{ko dru\{tvo 
Korytkova 7

SLO-1000 Ljubljana

Switzerland: Bundesamt für Strassen (ASTRA) des Eidgenössischen Departementes für Umwelt, Verkehr, Energie und Kommunikation (UVEK)

Fahrzeuge und Verkehrszulassung

Zulassungsausweise, Haftpflicht, Strafen

Bundesamt für Strassen

Hauptabteilung Strassenverkehr

CH 3003 Bern

Institut für Rechtsmedizin, Verkehrsmedizinische Abteilung

beim Strassenverkehrsamt Albisgüetli

Uetlibergstrase 301

CH-8036 Zürich

Turkey: Trafik Kazalarýný Önleme Daire BaPkanlýðý Dikmen-Ankara

Second set of addresses of National Licensing Authorities

Austria: Bundesministerium für Wissenschaft und Verkehr Radetzkystraße 2

A-1031 Wien

Belgium: Ministerie van Verkeer en Infrastructuur, Directie D2

Residence Palace, Bloc C, Bur.4207

Wetstraat 155

B-1040 Brussel

Ministère des Communications et de 1'Infrastructure Residence Palace, Rue de la loi 155

B-1040 Bruxelles

Denmark: Road Safety and Transport Agency

Adelgade 13

Postboks 9093

DK-1304 Kobenhavn K.

Finland: Ministry of Transport and Communications PL 235 Eteläesplanadi 16 FIN-00131 Helsinki

France: Ministère de 1'Equipement, des Transports et du Tourisme

Direction de la Sécurité et de la Circulation Routière Sous-Direction de la Formation du Conducteur

La Grande Arche Paroi Sud

F-92055 Paris la Défense Cedex 04

Germany: Bundesministerium für Verkehr - Aussenstelle Berlin

Krausenstrasse 17-20

D-10117 Berlin

Bundesministerium für Verkehr

Robert-Schumann-Platz 1
Postfach 200100

D-53170 Bonn

Greece: Ministère des Transports et des Communications

Direction Générale des Transports

Direction de la Circulation Routière

23, Syggrou Avenue

GR-11743 Athens

Ireland: Ministry of Environment

$\mathrm{O}^{\prime}$ Connell Bridge House

IRL-Dublin 2

Italy: Ministero dei Trasporti e della Navigazione

Direzione Generale della Motorizzazione Civile e dei Trasporti in concessione

Direzione Centrale IV - Divisione 46

Via Guiseppe Caraci 36

I-00517 Roma

Luxembourg: Ministère des Transports

19-21, Boulevard Royal

L-2938 Luxembourg

Netherlands: Ministerie van Verkeer en Waterstaat

Directoraat-Generaal Personenvervoer

Directie Verkeersveiligheid en Voertuig

Plesmanweg 1-6

Postbus 20901

NL-2500 EX Den Haag

Norway: Public Roads Administration

P.O.Box 8142 Dep.

N-0033 Oslo

Portugal: Ministerio Administração Interna

Direcção-Geral de Viação

Avenida da República, 16

P-1050 Lisboa

Spain: Ministerio de Justicia e Interior

Direccion General de Trafico

Subdirectora General de Investigacion y Formacion Vial

c/ Josefa Valcarel, 28

E-28071 Madrid

Sweden: Swedish National Road Administration

Vägverket, Körkortsavdelningen

Röda Vägen 1

S-78187 Borlänge

Ministry of Transport and Communication S-10333 Stockholm

United Kingdom: Dept of Environment, Transport and the Regions

Vehicle Licensing and Enforcement Division

Zone 2/11/B 
76, Marsham Street

GB-London SWIP 4DR

Driver and Vehicle Licensing Agency (DVLA)

DVLC, D9N

GB-Swansea SA6 7JL

\begin{abstract}
Acknowledgements. The authors would like to thank the following colleagues who contributed various information: T. Akerstedt, K. Bloch, A. Boudewijns, A. DeWeerd, L. Dolenc, N. Douglas, O. Ferenc, D. Garcia-Borreguero, G.L. Gigli, T. Gislason, M.Gugger, J. Hasan, J. Hedner, A. Jimenez-Gomez, H. Kaynak, M. Kerkhofs, P. Lavie, G. Mayer, C. MonasterioPonsa, J. Moutinho dos Santos, F. Obal, T. Podszus, K. Sonka, E. Stammova, J. Stradling, W. Szelenberg, T. Telakivi, P. Valenti, Z Tomori, M. Zamagni.
\end{abstract}

\section{References}

1. Young T, Peppard P. Epidemiology of obstructive sleep apnea. In: McNicholas WT, Phillipson EA, eds. Breathing Disorders in Sleep. London, W.B. Saunders, 2001; pp. 31-43.

2. Guilleminault C, Tilkian A, Dement WC. The sleep apnea syndromes. Annu Rev Med 1976; 27: 465-484.

3. Kurtz D, Krieger J. Analysis of apneas in sleep apnea. In: Liss A, ed. Sleep Apnea Syndromes. New York, Alan Liss, 1978; pp. 145-159.

4. Block AJ, Boysen PG, Wynne JW, Hunt LA. Sleep apnea, hypopnea, and oxygen desaturation in normal subjects. N Engl J Med 1979; 300: 513-517.

5. Gould GA, Whyte KF, Rhind GB, et al. The sleep hypopnea syndrome. Am Rev Respir Dis 1988; 137: 895-898.

6. Guilleminault C, Stoohs R, Clerk A, Cetel M, Maistros P. A cause of excessive daytime sleepiness. The upper airway resistance syndrome. Chest 1993; 104: 781-787.

7. Report of a Task Force of the American Academy of Sleep Medicine. Sleep-related breathing disorders in adults: recommendations for syndrome definition and measurement techniques in clinical research. Sleep 1999; 22: 667-689.

8. Young T, Palta M, Dempsey J, Skatrud J, Weber S, Badr S. The occurrence of sleep-disordered breathing among middle-aged adults. $N$ Eng $J$ Med 1993; 328: 1230-1235.

9. Lavie P. Sleep apnoea in industrial workers. In: Guilleminault C, Lugaresi E, eds. Sleep/Wake Disorders: Natural History, Epidemiology and Long-Term Evolution. New York, Raven Press, 1983; pp. 127-135.

10. Telakivi T, Partinen M, Koskenvuo M, Salmi T, Kaprio J. Periodic breathing and hypoxia in snorers and controls. Acta Neurol Scand 1987; 76: 69-75.

11. Gislason $T$, Almqvist $M$, Eriksson $G$, Taube A, Boman G. Prevalence of sleep apnoea syndrome among Swedish men - an epidemiological study. J Clin Epidemiol 1988; 41: 571-576.

12. Cirignotta $\mathrm{F}, \mathrm{D}^{\prime}$ Alessandro $\mathrm{R}$, Partinen $\mathrm{M}$, et al. Prevalence of every night snoring and obstructive sleep apnoeas among 30-69-year-old men in Bologna, Italy. Acta Psychiatr Scand 1989; 79: 366-372.
13. Stradling JR, Crosby JH. Predictors and prevalence of obstructive sleep apnoea and snoring in 1001 middle aged men. Thorax 1991; 46: 85-90.

14. Gislason $\mathrm{T}$, Benediktsdottir B, Bjornsson JK, Kjartansson G, Kjeld M, Kristbjarnarson H. Snoring, hypertension, and the sleep apnea syndrome. An epidemiologic survey of middle-aged women. Chest 1993; 103: 1147-1151.

15. Olson LG, King MT, Hensley MJ, Saunders NA. A community study of snoring and sleep-disordered breathing. Health outcomes. Am J Respir Crit Care Med 1995; 152: 717-720.

16. Bearpark H, Elliott L, Cullen $\mathrm{S}$, et al. Home monitoring demonstrates high prevalence of sleep disordered breathing in men in the Busselton (Western Australia) population. Sleep Research 1991; 20A: 411.

17. Gislason T, Benediktsdottir B. Snoring, apneic episodes, and nocturnal hypoxemia among children 6 months to 6 years old. An epidemiologic study of lower limit of prevalence. Chest 1995; 107: 963-966.

18. Ohayon MM, Guilleminault C, Priest RG, Caulet M. Snoring and breathing pauses during sleep: telephone interview survey of a United Kingdom population sample. BMJ 1997; 314: 860-863.

19. Kripke DF, Ancoli-Israel S, Klauber MR, Wingard DL, Mason WJ, Mullaney DJ. Prevalence of sleepdisordered breathing in ages 40-64 years: a populationbased survey. Sleep 1997; 20: 65-76.

20. Bixler EO, Vgontzas AN, Ten Have T, Tyson K, Kales A. Effects of age on sleep apnoea in men: I. Prevalence and severity. Am J Respir Crit Care Med 1998; 157: 144-148.

21. Duran J, Esnaola S, Rubio R, Iztueta A. Obstructive sleep apnea-hypopnea and related clinical features in a population-based sample of subjects aged 30 to 70 yr. Am J Respir Crit Care Med 2001; 163: 685-689.

22. Corbo G, Fuciarelli F, Foresi A, De BF. Snoring in children: association with respiratory symptoms and passive smoking. BMJ 1989; 299: 1491-1494.

23. Potsic W, Pasquariello P, Baranak C, Marsh R, Miller L. Relief of upper airway obstruction by adenotonsillectomy. Otolaryngol Head Neck Surg 1986; 94: 476-480.

24. Kripke D, Ancoli-Israel S. Epidemiology of sleep apnoea among the aged: Is sleep apnoea a fatal disorder? In: Guilleminault C, Lugaresi E, eds. Sleep/ Wake Disorders: Natural History, Epidemiology and Long-Term Evolution. New York, Raven Press, 1983; pp. 137-142.

25. Ancoli-Israel S, Coy T. Are breathing disturbances in elderly equivalent to sleep apnoea. Sleep 1994; 17: $77-$ 83.

26. Ancoli-Israel S, Kripke DF, Klauber MR, Mason WJ, Fell R, Kaplan O. Sleep-disordered breathing in community-dwelling elderly. Sleep 1991; 14: 486-495.

27. Bliwise D, Bliwise N, Partinen M, Pursley A, Dement W. Sleep apnoea and mortality in an aged cohort. Am J Public Health 1988; 78: 544-547.

28. Peppard PE, Young T, Palta M, Skatrud J. Prospective study of the association between sleep disordered breathing and hypertension. N Engl J Med 2000; 342: 1378-1384.

29. Lavie P, Herer P, Hoffstein V. Obstructive sleep apnoea syndrome as a risk factor for hypertension: population study. BMJ 2000; 320: 479-482.

30. Pepperell JC, Ramdassingh-Dow S, Crosthwaite N, 
et al. Ambulatory blood pressure after therapeutic and subtherapeutic nasal continuous positive airway pressure for obstructive sleep apnoea: a randomised parallel trial. Lancet 2002; 359: 204-210.

31. Schafer H, Koehler U, Ploch T, Peter JH. Sleeprelated myocardial ischemia and sleep structure in patients with obstructive sleep apnea and coronary heart disease. Chest 1997; 111: 387-393.

32. Peker Y, Hedner J, Kraiczi H, Loth S. Respiratory disturbance index is an independent predictor of mortality in coronary artery disease. Am $J$ Respir Crit Care Med 2000; 162: 81-86.

33. Nieto FJ, Young TB, Lind BK, et al. Association of sleep-disordered breathing, sleep apnea, and hypertension in a large community-based study. JAMA 2000; 283: 1829-1836.

34. Kiely JL, McNicholas WT. Cardiovascular risk factors in patients with obstructive sleep apnoea syndrome. Eur Respir J 2000; 16: 128-133.

35. Faccenda JF, Mackay TW, Boon NA, Douglas NJ. Randomized placebo-controlled trial of continuous positive airway pressure on blood pressure in the sleep apnea-hypopnea syndrome. Am J Respir Crit Care Med 2001; 163: 344-348.

36. Harbison J, O'Reilly P, McNicholas WT. Cardiac rhythm disturbances in the obstructive sleep apnea syndrome: effects of nasal continuous positive airway pressure. Chest 2000; 118: 591-595.

37. Bassetti C, Aldrich M. Sleep apnea in acute cerebrovascular diseases: Final report on 128 patients. Sleep 1999; 22: 217-223.

38. Wessendorf TE, Teschler H, Wang YM, Konietzko N, Thilmann AF. Sleep-disordered breathing among patients with first-ever stroke. J Neurol 2000; 247: 41-47.

39. Parra O, Arboix A, Bechich S, et al. Time course of sleep-related breathing disorders in first-ever stroke or transient ischemic attack. Am J Respir Crit Care Med 2000; 161: 375-380.

40. He J, Kryger MH, Zorick FJ, Conway W, Roth T. Mortality and apnoea index in obstructive sleep apnoea: experience in 385 male patients. Chest 1988; 94: 9-14.

41. Partinen M, Jameson A, Guilleminault C. Long-term outcome for obstructive sleep apnoea patients: mortality. Chest 1988; 94: 1200-1204.

42. Lavie P, Herer P, Peled R, et al. Mortality in sleep apnea patients: a multivariate analysis of risk factors. Sleep 1995; 18: 149-157.

43. Collins $\mathrm{R}$, Peto $\mathrm{R}$, MacMahon $\mathrm{S}$, et al. Blood pressure, stroke, and coronary heart disease. 2. Short-term reductions in blood pressure: overview of randomised drug trial in their epidemiological context. Lancet 1990; 335: 827-838.

44. Horne JA, Reyner LA. Sleep related vehicle accidents. BMJ 1995; 310: 565-567.

45. Maycock G. Sleepiness and driving: The experience of UK car drivers. J Sleep Res 1996; 5: 229-237.

46. Benbadis SR, Perry MC, Sundstad LS, Wolgamuth BR. Prevalence of daytime sleepiness in a population of drivers. Neurology 1999; 52: 209-210.

47. Aldrich MS. Automobile accidents in patients with sleep disorders. Sleep 1989; 12: 487-494.

48. Findley LJ, Unverzagt ME, Suratt PM. Automobile accidents involving patients with obstructive sleep apnea. Am Rev Respir Dis 1988; 138: 337-340.

49. Stradling JR, Crosby JH, Payne CD. Self-reported snoring and daytime sleepiness in men aged 35-65 years. Thorax 1991; 46: 807-810.

50. Young T, Blustein J, Finn L, Palta M. Sleepdisordered breathing and motor vehicle accidents in a population-based sample of employed adults. Sleep 1997; 20: 608-613.

51. Barbe F, Pericas J, Munoz A, et al. Automobile accidents in patients with sleep apnea syndrome. Am J Respir Crit Care Med 1998; 158: 18-22.

52. Teran-Santos J, Jimenez-Gomez A, Cordero-Guevara J. The association between sleep apnea and the risk of traffic accidents. $N$ Engl J Med 1999; 340: 881-883.

53. George CF, Boudreau AC, Smiley A. Simulated driving performance in patients with obstructive sleep apnea. Am J Respir Crit Care Med 1996; 154: 175-181.

54. Miller MM, Miller JC, Lipsitz JJ, et al. The sleep of long-haul truck drivers. N Engl J Med 1997; 337: 755761 .

55. Stoohs RA, Guilleminault C, Itoi A, Dement WC. Traffic accidents in commercial long-haul truck drivers: the influence of sleep-disordered breathing and obesity. Sleep 1994; 17: 619-623.

56. Engleman HM, Asgari-Jirhandeh N, McLeod AL, Ramsay CF, Deary IJ, Douglas NJ. Self-reported use of CPAP and benefits of CPAP therapy: a patient survey. Chest 1996; 109: 1470-1476.

57. Cassel W, Ploch T, Becker C, et al. Risk of traffic accidents in patients with sleep-disordered breathing: reduction with nasal CPAP. Eur Respir J 1996; 9: 2606-2611.

58. Krieger J, Meslier N, Lebrun $\mathrm{T}$, et al. Accidents in obstructive sleep apnea patients treated with nasal continuous positive airway pressure - A prospective study. Chest 1997; 112: 1561-1566.

59. George CFP. Reduction in motor vehicle collisions following treatment of sleep apnoea with nasal CPAP. Thorax 2001; 56: 508-512.

60. Strohl KP, Bonnie RJ, Findley L, et al. Sleep apnea, sleepiness and driving risk. Am J Respir Crit Care Med 1994; 150: 1463-1473.

61. Bennett LS, Stradling JR, Davies RJ. A behavioural test to assess daytime sleepiness in obstructive sleep apnoea. J Sleep Res 1997; 6: 142-145.

62. Johns MW. A new method for measuring daytime sleepiness: the Epworth sleepiness scale. Sleep 1991; 14: $540-545$

63. Lindberg E, Carter N, Gislason T, Janson C. Role of snoring and daytime sleepiness in occupational accidents. Am J Respir Crit Care Med 2001; 164: 2031-2035.

64. Anonymous. Cost justification for diagnosis and treatment of obstructive sleep apnea. Sleep 2000; 23: $1017-1018$.

65. Ronald J, Delaive K, Roos L, Manfreda J, Bahammam A, Kryger MH. Healthcare utilization in the 10 years prior to diagnosis in obstructive sleep apnea syndrome patients. Sleep 1999; 22: 225-229.

66. Otake K, Delaive K, Walld R, Manfreda J, Kryger $\mathrm{MH}$. Cardiovascular medication use in patients with undiagnosed obstructive sleep apnea. Thorax 2002; 57: 417-422.

67. Bahammam A, Delaive K, Ronald J, Manfreda J, Roos L, Kryger MH. Healthcare utilization in males with obstructive sleep apnea syndrome two years after diagnosis and treatment. Sleep 1999; 22: 740-748.

68. Kapur V, Blough DK, Sandblom RE, et al. The medical cost of undiagnosed sleep apnea. Sleep 1999; 22: 749-756. 